This article is distributed under the terms of the Creative Commons Attribution 3.0 PL ( ) Copyright by Uniwersytet Warszawski Katedra Studiów Interkulturowych Europy Środkowo-Wschodniej \& individual articles to their Authors

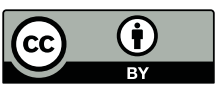

doi: 10.32612/uw.2543618X.2019.pp.518-519

Przegląd Środkowo-Wschodni, 4, 2019

ISSN 2543-618X elSSN 2545-1324

$\mathrm{Nr}$ art. 20190419

Data przesłania: 01.02 .2018

Data akceptacji: 23.05.2018

Андрэй Вашкевіч

Гродзенскі дзяржаўны гісторыка-археалагічны музей

horadzien@gmail.com

ORCiD: 0000-0002-9257-2721

\title{
«Зменлівыя колеры Ліпска» Юрыя Туронка
}

Вясной 2009 года мне давялося сустрэцца з Юрыем Туронкам у яго ўтульнай кватэры на вуліцы Тамка, 49 у Варшаве. Да гэтага часу я ўжо нейкі час перапісваўся з паважаным гісторыкам, атрымліваў каштоўную дапамогу і парады.

Напрыклад, у бібліятэцы былой Польскай аб'яднанай рабочай партыі Ю. Туронак адшукаў для мяне надзвычай рэдкі экзэмпляр выдадзенай у 1934 годзе прапагандысцкай брашуры «Як беларуская хадэцыя гандлюе крывёю рабочых і сялян».

Падчас варшаўскага спаткання, паміж іншым, зайшла размова пра кнігу «Паміж Ласоснай і Чорнай Ганчай», якую я незадоўга да таго даслаў спадару Юрыю. У кнізе расказвалася пра ваколіцы Гродна, дзе дзяржаўная граніца ў 1944 годзе падзяліла вельмі цікавы гістарычны мікрарэгіён, на тэрыторыі якога да 1875 года сярод беларускага насельніцтва пратрымалася грэка-каталіцтва ${ }^{1}$. На беларускім баку засталося мястэчка Сапоцкін, да Польшчы адышоў Ліпск і навакольныя вёскі.

«А я не аднойчы бываў у Ліпску, - сказаў спадар Юры. - Нават у 1976 годзе напісаў пра гэтыя мясціны артыкул. Праўда, часопіс,

1 А. Вашкевіч, Д. Нарэль, Паміж Ласоснай $і$ Чорнай Ганчай. Гісторыя каталіикіх парафій у паўднёва-ўсходняй частиь Аўгустойскай пушчы, Мінск 2006. 
у які я паслаў артыкул, так яго і не надрукаваў. Вось, вазьміце тэкст разам з фотаздымкамі, можа, вам прыдасца».

Машынапіс артыкула Ю. Туронка „Zmienne barwy Lipska” («Зменлівыя колеры Ліпска») праляжаў у мяне амаль дзесяць гадоў. Цяпер яго можа, нарэшце, прачытаць шырокая публіка.

Пішучы артыкул для польскага выдання, Ю. Туронак найбольш засяродзіўся на рэлігійнай гісторыі Ліпска і ваколіц і не падкрэсліў, што прымусовы перавод уніятаў у праваслаўе ў 1875 годзе і пазнейшыя «ўцёкі» праваслаўных у каталіцтва мелі важныя наступствы для фарміравання нацыянальнай свядомасці мясцовага насельніцтва.

Выказаная Ю. Туронкам канцэпцыя пра паходжанне ліпскіх каталікоў 3-над Нёмана, а праваслаўных з-над Буга праўдзівая толькі часткова. Як сведчаць крыніцы, насельніцтва, якое перасялялася з боку Нёмана, было праваслаўным, а людская плынь з Валыні не перайшла на поўнач далей за сучасны Беласток. Магчыма, заснаванне каталіцкіх парафій было звязана са стварэннем рэлігійных цэнтраў сярод мясцовага балцкага насельніцтва. Рымска-каталіцкія прыходы былі таксама цэнтрамі рэлігійнага жыцця шляхты і ствараліся ў большых населеных пунктах (такіх, як Ліпск) для купцоў і рамеснікаў.

Ю. Туронак сказаў, што Ліпск 1976 года быў ужо «аднакаляровы» - польскі. Сёння Беларусь і Польшча рэалізуюць у гэтым рэгіёне трансгранічныя праекты. Беларусь адмяніла візы для тых, хто па Аўгустоўскім канале едзе ў ваколіцы Сапоцкіна. Ёсць праект турыстычнага пагранічнага перахода Сафіёва-Ліпшчаны. Жыхары Ліпска цікавяцца сваім мінулым, некаторыя з іх з'яўляюцца сябрамі суполкі ў фэйсбуку, прысвечанай «простай» (беларускай) мове.

Артыкул Ю. Туронка варта прачытаць як мясцовым жыхарам, так і ўсім, хто цікавіцца гісторыяй беларуска-польскага памежжа. 